\title{
PENGGUNAAN BONEKA SEBAGAI MEDIA SIMULASI KREATIF DI SEKOLAH DASAR
}

\author{
Sri Agustin Mulyani \\ e-mail: adhi.hernandez@yahoo.com
}

\begin{abstract}
The characteristic of doll in children's life is as a manipulative playing tool which is suitable in expressing children's feeling in order to solve some problems occurred in the reflection of their daily life activities. Recently, doll, as a learning media, is still being used by teachers. This happens as teachers consider doll to be a natural model to tell stories or happenings. In the implementation of doll as the media of learning, there are four commonly used kinds of doll, they are; (1) handle doll (doll with handle to play with), (2) hanged-doll, (3) stick-doll, and (4) fingers-doll. The learning process, dealing with doll's performance, is categorized into two, they are two dimensions and three dimension stage performance. The utilizing of doll as a means of creative media is only the simulation of children's life that is being played by the person who moves the doll. The evaluation of doll's performance consists of dialogue, pronunciation, the exact manner of expression, and internalization of each character of the doll. Meanwhile, a check list ia chosen to be the best evaluation instrument.
\end{abstract}

\begin{abstract}
Abastrak: Karakteristik boneka dalam kehidupan anak-anak adalah sebagai salah satu alat permainan manipulasi yang cocok untuk menyalurkan perasaan dalam upaya untuk memecahkan masalah. Boneka sebagai media pembelajaran masih menjadi pilihan guru saat ini, hal ini disebabkan boneka menjadi alat peraga yang dianggap naturalitas dalam bercerita. Pelaksanaan pembelajaran dengan boneka sebagai media pembelajaran dilakukan dengan menggunakan empat jenis boneka, yaitu: (1) boneka gagang, (2) boneka gantung, (3) boneka tempel, dan (4) boneka jari. Performasi pembelajaran dikatagorikan dalam dua jenis, yaitu melalui panggung boneka dua dimensi, dan tiga dimensi. Penggunaan boneka sebagai sarana simulasi kreatif diperankan secara tidak langsung yaitu mewakili orang yang menggerakkan boneka tersebut. Penilaian kegiatan meliputi dialog, ucapan lafal yang tepat dan penghayatan, sedangkan alat penilaian menggunakan daftar cek dan pedoman penilaian.
\end{abstract}

Kata kunci: boneka, media simulasi kreatif

Istilah bermain sambil belajar membawa implikasi bahwa guru perlu merancang program yang memungkinkan anak belajar melalui bermain. Kegiatan bermain perlu dirancang sedemikian rupa sehingga anak tidak merasa jenuh. Mengetahui perkembangan bermain anak hanyalah salah satu dari aspek menyeleksi permainan yang tepat untuk anak.

Piaget maupun Vygotsky menandaskan bahwa bermain berkaitan erat dengan representasi, bagaimana anak menggambarkan dunia dan mengekspresikan perasaan dan kebutuhannya.
Pandangan pakar pendidikan tentang pembelajaran yang berdasarkan pada bermain cukup kuat. Melalui bermain anak memiliki kemampuan untuk memahami konsep-konsep secara alamiah dan tanpa dipaksakan (Mayke, dalam Sudono, 1995). Montessori seorang tokoh pendidikan menekankan bahwa anak belajar dan menyerap apa saja yang ditemukan dalam lingkungannya. Menurut Montessori, perencanaan dan persiapan lingkungan belajar anak harus dibuat sedemikian rupa sehingga segala sesuatu bisa dijadikan kesempatan belajar yang dapat diserap anak, salah satunya adalah 
melalui kegiatan bermain (Hainstock, 1978).

Menurut Mayke (dalam Sudono, 1995) bahwa belajar dengan bermain memberi kesempatan kepada anak-anak untuk memanipulasi, mengulang-ulang, menemukan, mengeksplorasi, mepraktikkan dan mendapatkan bermacammacam konsep serta pengertian yang tidak terkira banyaknya. Disinilah proses pembelajaran terjadi, anak dapat mengambil keputusan, memilih, menentukan, menciptakan, mengeluarkan pendapat dan memecahkan masalah, bekerja sama dengan teman, serta mengalami berbagai macam perasaan. Makna bermain ini tentunya memerlukan sarana yang tepat dan sesuai kegunaannya serta disesuaikan dengan perkembangan anak dalam berbagai aspek.

\section{Karakteristik Boneka dalam Kehidupan Anak-Anak}

Bermain merupakan suatu kegiatan yang melekat pada dunia anak. Bermain juga merupakan kodrat anak. Bermain dapat dipandang sebagai suatu kegiatan bersifat spontan, berfokus pada proses, memberi ganjaran intrinsik, menyenangkan dan fleksibel.

Fungsi bermain bagi anak adalah menirukan apa yang dilakukan orang dewasa, untuk melakukan berbagai peran yang ada dalam kehidupan. Anak memerlukan suatu alat permainan yang dapat menyalurkan perasaannya dan upaya untuk mencoba memecahkan masalah. Salah satu alat permainan manipulasi yang cocok untuk memenuhi kebutuhan tersebut adalah boneka.

Boneka yang tersebar di toko-toko dengan aneka bentuk menarik dapat digunakan sebagai pemicu gagasan bagi anak, namun yang perlu diperhatikan bahwa pemilihan boneka tetaplah berorientasi pada nilai pendidikan dalam kehidu- pan anak, bukan nilai komersial boneka itu sendiri. Boneka hendaklah menjadi teman dialog bagi anak untuk mengembangkan ide-idenya dalam cakrawala berpikir yang luas. Semakin banyak variasi jenis boneka, semakin kaya perbendaharaan kata yang dihasilkan oleh anak.

Pemilihan jenis boneka dalam kehidupan anak berkembang sesuai dengan tingkatan usia. Boneka anak usia prasekolah tentu saja berbeda dengan anak usia SD. Hal ini dipengaruhi oleh tingkat perkembangan dan minat anak dalam berbahasa.

Malone (dalam Musfiroh, 2005) menandai karakteristik dari permainan termasuk boneka, yaitu (a) menarik bagi anak, (b) sesuai dengan kapasitas fisik anak, (c) sesuai dengan perkembangan mental anak, (d) sesuai dengan kelomok anak-anak dan tahan lama atau aman bagi anak.

\section{Boneka sebagai Media Pembelajaran}

Boneka adalah salah satu alat peraga tiruan yang sejak lama digunakan dalam pembelajaran. Pemanfaatan boneka sebagai alat peraga masih menjadi pilihan para guru saat ini, hal ini disebabkan karena boneka menjadi alat peraga yang dianggap mendekati naturalitas dalam bercerita. Tokoh-tokoh yang diwujudkan melalui boneka, berbicara dengan gerakan-gerakan yang mendukung pembelajaran dan mudah diikuti anak. Melalui boneka anak tahu tokoh mana yang sedang berbicara, apa isi pembicaraan dan bagaimana perilakunya. Boneka kadang menjadi sesuatu yang hidup dalam imajinasi anak (Musfiroh, 2005).

Bercerita dengan boneka membutuhkan persiapan yang lebih matang, terutama persiapan memainkan boneka. Keterampilan menggerakkan jari dengan lincah menjadi bagian penting dalam memainkan peran para tokoh. Keteram- 
pilan memainkan boneka menjadi faktor penentu keberhasilan.

Untuk memainkan boneka yang dipakai sebagai media pendidikan perlu memperhatikan beberapa hal yaitu:

1. Permainan boneka ditekankan pada aksi dari pada kata-kata. Anak dapat mengembangkan daya imajinasi melalui gerakan boneka, aksi boneka akan dapat menggambarkan alur cerita yang akan dipahami oleh anak, tentu saja aksi yang dimainkan tetap dalam proporsi kewajaran sehingga nilai-nilai pengembangan pembelajaran dapat diserap oleh anak.

2. Cerita yang dibawakan tidak berteletele. Alur cerita singkat tetapi tetap menggambarkan detail peristiwa dengan lengkap.

3. Permainan singkat dan anak mengharapkan boneka berbuat sesuatu. Permainan boneka yang terlalu lama akan membuat anak menjadi bosan dan berakhir dengan kegaduhan. Akan lebih baik di sela-sela bercerita guru membuat sesuatu permainan dialog antara boneka dan anak.

4. Permainan sebaiknya diiringi musik. Kehadiran musik pengiring dapat dimanfaatkan ketika tokoh menyanyikan lagu bersama anak dan kegiatan ini dapat menghidupkan suasana menjadi lebih menyenangkan.

5. Permainan hendaknya disesuaikan dengan pengalaman anak. Hal ini aakan lebih menarik minat anak karena penanaman nilai-nilai dalam kehidupan akan lebih mudah dipahami oleh anak.

6. Permainan tidak kaku. Kedua tangan guru harus lentur memainkan boneka, adakalanya melakukan gerakan secara bersama-sama (karena sedang bicara) adakalanya diam (karena menunggu giliran bicara).

7. Agar menarik, cerita hendaknya memelibatkan siswa Guru dapat menye- lipkan beberapa pertanyaan non cerita sebagai pengisi cerita, sekaligus strategi melibatkan anak.

\section{Penataan Performasi dan Isi Pembelajaran}

\section{Penataan Performasi}

Pelaksanaan pembelajaran dengan menggunakan boneka sebagai media pembelajaran dapat dilakukan dengan menggunakan beberapa jenis boneka yaitu boneka gagang (termasuk wayang), boneka gantung, boneka tangan, dan boneka tempel. Setiap boneka memerlukan tumpuan ketrampilan tangan tersendiri.

a. Boneka Gagang

Mengandalkan keterampilan mensinkronkan gerak gagang dengan tangan kanan dan kiri.

b. Boneka Gantung

Mengandalkan keterampilan menggerakkan boneka dan benang yang diikatkan pada kayu, lidi atau panggung.

c. Boneka Tempel

Mengandalkan keterampilan memainkan gerak tangan. Tidak leluasa bergerak karena ditempel pada panggung dua dimensi.

\section{d. Boneka Tangan}

Mengandalkan keterampilan guru dalam menggerakkan ibu jari dan telunjuk yang berfungsi sebagai tulang tangan.

Untuk performasi pembelajaran dengan boneka guru dapat menyiapkan panggung boneka yang dapat dikategorikan dalam dua jenis yaitu:

a. Panggung Boneka Dua Dimensi

Dibuat untuk boneka tempel dan boneka gantung. Hiasan panggung dapat dibuat dari bahan alam (daun-daunan) yang dilekatkan, dapat pula dibuat gambar langsung pada panggung. Boneka gagang digerakkan dengan gagang sedangkan boneka tempel dapat di- 
gerakkan dari balik layar maupun digerakkan dari bawah oleh guru dengan bantuan lidi atau tali.

b.Panggung Boneka Tiga Dimensi

Dipergunakan untuk boneka tangan atau boneka gantung. Panggung tiga dimensi ruangannya dapat dibuat dari kardus maupun kayu, panggung ini dilengkapi dengan penghias. Semua komponen panggung dapat dilihat pada bagian belakang, sekaligus dapat dimanfaatkan untuk latar pemandangan. Panggung ini dilengkapi dengan alas terbuka yang berfungsi sebagai pengendali boneka, tingginya disesuaikan dengan kebutuhan.

\section{Isi Pembelajaran}

Untuk penggunaan boneka sebagai media pembelajaran adalah untuk (a) melatih keterampilan ekspresi lisan (keterampilan berbicara), (b) membina dan mengembangkan sikap dan tingkah laku yang baik, (c) melatih percaya diri, dan (d) mengembangkan fantasi dan imajinasi.

Untuk membina dan mengembangkan sikap perilaku yang baik dilakukan oleh anak melalui peniruan tokoh-tokoh yang dapat diterapkan dan dikembangkan dalam kehidupannya. Rasa percaya diri tampak ketika anak menyelesaikan tugas bercerita dan memantapkan berdialog di depan teman-temannya, sedangkan kegiatan pengembangan imajinasi dan fantasi terlihat ketika anak menghadirkan sesuatu dalam pikiran dan perasaan terhadap perilaku tokoh dan alur cerita.

\section{Penggunaan Boneka sebagai Sarana Simulasi Kreatif}

Penggunaan boneka sebagai sarana simulasi kreatif pada dasarnya tidak berbeda dengan bentuk-bentuk simulasi ya- ng lain. Letak perbedaannya ialah pada pemegang peran atau pemainnya. Bentuk simulasi yang lain menggunakan peranan yang bersifat langsung, maka pada penggunaan boneka ini peran tersebut diperankan secara tidak langsung. Pemeran yang tdak langsung ini menggunakan boneka yang pada dasarnya hanya mewakili pemeran yang sebenarnya, yaitu orang yang menggerakkan boneka tersebut.

Langkah-langkah perencanaan penggunaan boneka sebagai sarana simulasi kreatif adalah sebagai berikut:

1. Memilih cerita yang memiliki kriteria pemilihan cerita seperti yang ditemukan oleh Tompkins (dalam Mustakim, 2005), yaitu (a) mempunyai plot sederhana dan tersusun baik, (b) mempunyai permulaan, pertengahan dan akhir cerita yang jelas/unit cerita, (c) memiliki tema dasar, (d) mempunyai karakter yang jelas, dan (e) berisi dialog.

2. Membuat langkah persiapan simulasi kreatif dengan membaca cerita berulang kali agar dapat menghayati dan memahami alur dan peristiwa dalam cerita.

3. Menetapkan penggalan-penggalan cerita berupa dialog yang dijadikan bahan simulasi kreatif, kemudian merancang cara permainannya.

4. Menetapkan jumlah pemeran dialog dan memberi gambar tokoh-tokoh pada masing-masing pemeran sehingga memudahkan anak melakukan kegiatan.

5. Memberikan dialog lisan yang mudah diingat anak atau dihafal anakanak sesuai dengan yang diperankan.

6. Merencanakan kegiatan, kapan melakukan dialog dan bagaimana cara mengatur permainan dialog.

7. Memberikan motivasi dan bantuan bagi anak yang mengalami kesuli$\tan$. 
8. Mempersiapkan alat bantu seperti gambar-gambar tokoh, tokoh binatang dan boneka yang dapat menunjang permainan.

Setelah menetapkan langkah-langkah perencanaan penyajian simulasi kreatif, maka guru menciptakan pentas khayalan bagaimana anak mendialogkan, kapan dan dimana posisi anak melakonkan dialog dalam kelas, ketika rancangan ini sudah mantap maka dalam kegiatan pelaksanaan tidak mengalami kesulitan. Berdasarkan perencanaan persiapan dibuatlah langkah-langkah pelaksanaan simulasi kreatif dengan menggunakan boneka.

1. Guru memberi penjelasan mengenai pentingnya permainan tersebut dan hal-hal yang harus dilakonkan oleh anak dalam melaksanakan permainan.

2. Guru memberi contoh cara memainkan boneka, dalam memainkan boneka hendaknya diusahakan agar gerakan-gerakan boneka itu kelihatan hidup. Yang tampak diatas panggung hanya boneka-boneka yang dimainkan, dan orang yang memainkan sedapat mungkin tidak keliha$\tan$.

3. Beberapa anak ditunjuk untuk memainkan boneka yang mewakili tokoh-tokoh atau perilaku dalam cerita.

4. Pelaksanaan permainan tersebut dilakukan beberapa anak, seorang anak memainkan boneka atau memainkan satu tokoh.

5. Anak lain yang belum bermain diberi kesempatan untuk bermain. Penampilan kelompok yang belum bermain dapat memainkan dengan cara serupa.

6. Anak-anak diberi kesempatan untuk menyatakan komentarnya tentang penampilan kelompok lain, agar bisa memahami kelebihan dan kekurang- annya setelah bermain simulasi kreatif dengan boneka.

\section{Penilaian Pelaksanaan Kegiatan}

Berdasarkan proses pembelajaran bermain simulasi kreatif menggunakan boneka yang dilakukan dalam kelas, maka penilaian proses untuk mengukur kemampuan dan keterampilan anak dilakukan penilaian pengamatan sesuai tujuan pembelajaran. Aspek penilaian berisi; (a) penggunaan bahasa seperti ketepatan ucapan, kelancaran, susunan kalimat, dan pilihan kata yang tepat, (b) sikap penampilan seperti kewajaran, kesanggupan dan kelancaran, (c) pengungkapan ekspresi yang wajar, sesuai dengan peran yang dibawakan.

Kriteria dan kualifikasi penilaian keberhasilan anak dinyatakan dengan perolehan skor maksimal 100. Kualifikasi dengan sangat baik dinyatakan dengan nilai 85-100, kualifikasi baik dengan nilai 74-84, kualifikasi cukup dengan nilai 55-69, kualifikasi kurang dengan nilai 40-54 dan kualifikasi sangat kurang dengan nilai 0-40. Melalui alat ukur seperti ini anak memperoleh hasil secara objektif dan tepat dalam sistem penilaian pembelajaran bermain simulasi kreatif dengan menggunakan boneka.

\section{Simpulan dan Saran}

Penggunaan boneka sebagai media simulasi kreatif di Sekolah Dasar dapat mengembangkan keterampilan berbahasa lisan atau keterampilan berbicara dan membina sikap perilaku yang baik yang dilakukan anak melalui peniruan tokohtokoh yang dapat diterapkan dan dikembangkan dalam kehidupan sehari-hari. Penggunaan boneka sebagai media simulasi kreatif merupakan suatu strategi yang dapat meningkatkan kemampuan siswa mengapresiasi sebuah cerita dan me- 
merankan tokoh-tokoh dengan penghayatan yang sesuai dengan peran masingmasing. Pembelajaran apresiasi cerita atau dongeng di Sekolah Dasar diperlukan perencanaan, pelaksanaan dan penilaian pembelajaran yang tepat.

Berdasarkan simpulan di atas disarankan kepada guru Sekolah Dasar untuk menerapkan strategi simulasi kreatif dengan menggunakan media boneka sebagai salah satu alternatif pembelajaran apresiasi cerita atau dongeng. Guru Sekolah Dasar sebaiknya memilih bahan pembelajaran yang sesuai dengan tingkat perkembangan anak.

\section{Daftar Rujukan}

Haiinstock, Elizabeth G. 1978: Teaching Montessori In The Home: The Prescholl Yeard. Middlesey, England: Plume Publ.

Mustakim. 2005. Peranan Cerita Dalam Pembentukan Perkembangan Anak $T K$. Jakarta: DEPDIKNAS.

Musfiroh. 2005. Berceritera Untuk Anak Usia Dini. Jakarta: DEPDIKNAS.

Sudono. A. 1985. Alat Permainan dan Sumber Belajar TK. Jakarta: DIRJEN DIKTI.

Udin. T. 1988. Ilmu Pendidikan Sekolah Pendidikan Guru. Bandung: Epsilon Grup

Zainul, Mulyana. 2005. Tes dan Asesmen di SD. Jakarta UT 